\title{
Stickler syndrome: further mutations in COL11A1 and evidence for additional locus heterogeneity
}

\author{
Sam Martin ${ }^{1}$, Allan J Richards ${ }^{1}$, John RW Yates ${ }^{2}$, John D Scott ${ }^{3}$, Michael Pope ${ }^{4}$ and \\ Martin P Snead ${ }^{3}$ \\ ${ }^{1}$ Department of Pathology, University of Cambridge \\ ${ }^{2}$ Department of Medical Genetics, University of Cambridge, Addenbrooke's NHS Trust \\ ${ }^{3}$ Vitreoretinal Service, Addenbrooke's NHS Trust, Cambridge, UK \\ ${ }^{4}$ Institute of Medical Genetics, University Hospital of Wales, Cardiff, UK
}

\begin{abstract}
Stickler syndrome (hereditary arthro-ophthalmopathy) is a dominantly inherited connective tissue disorder with ocular, oro-facial, auditory and skeletal manifestations. It is genetically and phenotypically heterogeneous with the majority of families having mutations in the gene encoding type II collagen (COL2A1) and exhibiting a characteristic 'membranous' or type 1 vitreous phenotype. More recently a novel mutation in the gene encoding the $\alpha 1$ chain of type XI collagen (COL11A1) was reported in a Stickler syndrome pedigree with a different 'beaded' or type 2 vitreous phenotype. In the present study five more families with the type 2 vitreous phenotype were examined for linkage to four candidate genes: $C O L 2 A 1, C O L 5 A 2$, $C O L 11 A 1$ and $C O L 11 A 2$. Two families were linked to $C O L 11 A 1$ and sequencing identified mutations resulting in shortened $\alpha 1(\mathrm{XI})$ collagen chains, one via exon skipping and the other via a multiexon deletion. One of the families showed weak linkage to $C O L 5 A 2$ but sequencing the open reading frame failed to identify a mutation. In the remaining two families all four loci were excluded by linkage analysis. These data confirm that mutations in COL11A1 cause Stickler syndrome with the type 2 vitreous phenotype and also reveal further locus heterogeneity.
\end{abstract}

Keywords: collagen; retinal detachment; Stickler syndrome; vitreous

\section{Introduction}

Stickler syndrome (hereditary arthro-ophthalmopathy; MIM108300; 184840) is a dominantly inherited disorder of connective tissue with characteristic ophthalmic, orofacial, auditory and articular manifestations. ${ }^{1,2}$ It is the

Correspondence: Martin Snead, Vitreoretinal Service, Box 41, Addenbrooke's NHS Trust, Hills Road, Cambridge, CB22QQ, England, UK. Tel: 01223216701; Fax: 01223 217968; E-mail: mps34@cam.ac.uk

Received 21 January 1999; revised 29 March 1999; accepted 15 June 1999 commonest cause of inherited retinal detachment which is frequently bilateral and if untreated, leads to blindness. Abnormalities of vitreous formation and gel architecture are pathognomonic of Stickler syndrome. ${ }^{3}$ Other characteristic features include congenital myopia (short-sight), midline clefting, a flattened mid-facial appearance, sensorineural hearing loss and joint hypermobility and later in life a degenerative arthropathy. There is a variation in expression both within and between families. Linkage of the disorder to the gene for type II collagen (COL2A1) a major component of both cartilage and vitreous, has been shown in some 
families but not others. ${ }^{4-7}$ The first causative mutations in Stickler patients were identified in the COL2A1 gene, ${ }^{8,9}$ which was also mutated in the original Stickler kindred. ${ }^{10}$ Mutations of various types have been found including deletions, mis-splicing and single base mutations. ${ }^{11}$ So far, all have resulted in premature termination codons, leading to haploinsufficiency. Dominant negative changes in COL $2 A 1$ usually result in more severe phenotypes such as Kniest dysplasia and hypochondrogenesis. ${ }^{11}$

We have previously reported that in Stickler syndrome two distinct vitreoretinal phenotypes can be recognised. ${ }^{12-14}$ In the majority of patients an apparently vestigial vitreous gel occupies the immediate retrolental space and is bordered by a distinct folded membrane. We have referred to this characteristic 'membranous' anomaly as the type 1 vitreous phenotype and have shown that it correlates with defects in COL $2 A 1{ }^{12}$ In the remaining pedigrees there is a different phenotype with sparse fibre bundles of variable diameter coursing throughout an apparently otherwise optically empty vitreous cavity. We have referred to this 'beaded' or 'string of pearls' appearance as the type 2 vitreous phenotype and in these pedigrees linkage to COL2A1 has been excluded. ${ }^{12,13}$ These different vitreous phenotypes are illustrated in a recent review. $^{15}$

In one family with the type 2 vitreous phenotype, we have demonstrated linkage to $C O L 11 A 1^{13}$ and shown the causative mutation to be substitution of a glycine residue in the collagen helix, likely to have a dominant negative effect. ${ }^{16}$ It is now apparent that that the quantitatively minor type $\mathrm{V}$ and $\mathrm{XI}$ collagens form heterotypic fibrils with the more abundant type II fibrillar collagen and help to regulate fibril assembly and diameter. ${ }^{17,18}$ Type XI collagen is more abundant in tissues expressing type II collagen so it is to be expected that mutations in either COL2A1 or COL11A1 can cause Stickler syndrome. However, COL11A2 is not expressed in the vitreous which explains why mutations in this gene give rise to some manifestations of Stickler syndrome but without eye abnormalities. ${ }^{19-22}$ In bovine vitreous it has been shown that the $\alpha 2$ chain of type XI collagen is replaced by the $\alpha 2$ chain of type $\mathrm{V}$ collagen, ${ }^{23}$ a product of the COL5A2 gene, which can therefore also be considered as a candidate gene for Stickler syndrome.

The combination of phenotypic and genetic heterogeneity complicates the classification of Stickler syndrome and related disorders. A locus-based classifica- tion has been suggested ${ }^{22}$ differentiating the full Stickler syndrome from the non-ocular variants although this is different from that given by OMIM (online Mendelian inheritance in man). Our clinical sub-classification $^{12}$ based on vitreous phenotype is more in harmony with the former and should not be confused with the locus-based classification of Stickler syndrome used in OMIM in which the designations STL1, STL2 and STL3 are assigned to COL2A1, COL11A2 and COL11A1 respectively.

In this study we report analysis of further families with the type 2 vitreous phenotype, characterise further mutations in COL11A1 and provide evidence for another Stickler syndrome locus.

\section{Materials and Methods}

The study was granted ethical approval (LRC92/019) and pedigrees were identified from the vitreoretinal service database at Addenbrooke's Hospital and subclassified according to phenotype prior to molecular genetic analysis. Since there are no definitive published criteria for the diagnosis of Stickler syndrome, a suggested protocol for diagnosis which was used in this study is given below:

1) Congenital abnormality of vitreous development, ${ }^{12,14,15}$ and in addition, any three of the following features:

2) Stable congenital myopia with onset prior to 6 years of age;

3) Rhegmatogenous retinal attachment or paravascular pigmented lattice degeneration;

4) Joint laxity with or without radiological evidence of joint degeneration;

5) Audiometric confirmation of sensorineural hearing defect;

6) High arched or cleft palate.

No patients had anhidrotic ectodermal dysplasia, acute cataract or hypertelorism as described in Marshall syndrome (MIM 154780), ${ }^{24,25}$ and other oro-facial features of Marshall syndrome show considerable overlap with those of Stickler syndrome. ${ }^{24,25}$

\section{Linkage Analysis}

Primer sequences for markers close to the four candidate genes were obtained from the Généthon map ${ }^{26}$ and Genemap. ${ }^{27}$ Primers for the COL2A1 $3^{\prime}$ VNTR were as described previously. ${ }^{12}$ Other markers used for COL2A1 were D12S85 and D12S83. Flanking markers D1S223, D1S206, D1S495 and D1S248 were used for COL11A1 and D6S105, D6S276, D6S291 were used for COL11A2. A dinucleotide repeat in intron 25 of COL $3 \mathrm{~A} 1^{28}$ was used as a marker for COL5A2, as these two genes are very closely related. ${ }^{29}$ Additional markers used for COL5A2 were D2S389 and D2S2261. All of these markers were used to amplify polymorphic DNA variants from the subjects under investigation. One primer in each 
pair was end labelled with ${ }^{33} \mathrm{P}$ and then used in conjunction with the unlabelled primer in amplification reactions containing 20mm Tris $\mathrm{HCl} \mathrm{pH} 8.4,50 \mathrm{~mm} \mathrm{KCl}, 5 \mathrm{~mm} \mathrm{MgCl}_{2}, 200 \mu \mathrm{M}$ dNTPs, 12.5 pmol of each primer and 0.5 units of Taq DNA polymerase in a volume of $12.5 \mu \mathrm{l}$. Standard cycling parameters were $95^{\circ} \mathrm{C} 1 \mathrm{~min}, 55^{\circ} \mathrm{C} 1 \mathrm{~min}$ and $72^{\circ} \mathrm{C} 1 \mathrm{~min}$ for 30 cycles. Products were analysed by electrophoresis in denaturing polyacrylamide gels and autoradiography. Lod scores were calculated using LIPED. $^{30}$

\section{Analysis of COL11A1}

Amplification of COL11A1 cDNA was achieved using RNA from cultured dermal fibroblasts as previously described. ${ }^{16}$ The complete open reading frame was amplified as seven overlapping products of around $900 \mathrm{bp}$. Larger products of around $3 \mathrm{~kb}$ were also synthesised using a different combination of the primers. In both instances a primary amplification reaction was re-amplified using a nested antisense primer to obtain the final cDNA product. For the larger cDNAs Superscript ${ }^{\mathrm{TM}}$ (Life Sciences) was used in the reverse transcription reactions and TaqPlus ${ }^{\mathrm{TM}}$ (Stratagene) was used in the amplification reactions, as recommended by the manufacturers.

Amplification of various regions of COL11A1 from genomic DNA was undertaken using TaqPlus, primers derived from the COL11A1 cDNA sequence (Genbank accession number J04177; J05407, ${ }^{22}$, and the gene structure of $C O L 11 A 2^{31}$ as a guide to the exon/intron organisation of COL11A1. All amplified genomic products were partially sequenced to confirm the location of introns, and detect mutations in affected individuals. Analysis of DNA from individuals from family MS42 was achieved by amplification using primers derived from intron sequences, one upstream from the skipped exon and the other downstream. These were 5' ggtgcaattggcaggataaaagtag 3' (sense) and 5' gatgcattctcgaaggaattatgc 3' (antisense). The product was incubated with the restriction enzyme $S f c I$ at $37^{\circ} \mathrm{C}$ and then analysed by agarose gel electrophoresis.

\section{Analysis of COL5A2}

The strategy for analysis of $C O L 5 A 2 \mathrm{cDNA}$ was the same as for $C O L 11 A 1$. Primers were derived from the published cDNA sequences (Genbank accession number Y14690) and used to amplify six products covering bases 100-1419; 886-2133; 1624-3330; 2812-4047; 3190-4434; and 3937-4626. In addition larger products covering bases 100-2280; 2002-4626; and 498-4434 were amplified. In each case the primers corresponded to the first 24 sense and last 24 anti- sense bases. The smaller products were directly sequenced as above.

\section{Results}

\section{Linkage Analysis}

Linkage analysis was performed on five families with the type 2 vitreous phenotype using markers close to the COL2A1, COL5A2, COL11A1 and COL11A2 genes and the results are given in Table 1. Loci were excluded if:

a) Affected individuals were recombinant for a markers very close to the candidate genes ( 3 VNTR for $C O L 2 A 1$, and $C O L 3 A 1$ for $C O L 5 A 2$ ); or

b) Affected individuals had inherited different haplotypes for flanking markers.

For families MS40 and MS42, COL11A1 was the best candidate with linkage to the other candidate loci excluded according to the criteria defined above. Clinical data for affected individuals from these pedigrees are given in Tables 2 and 3 respectively. Analysis of family MS40 showed that D1S495 was linked to the disorder $\left(\mathrm{Z}_{\max } 3.3, \theta=0\right)$, implicating $C O L 11 A 1$ as the disease locus. In family MS42 the disorder was linked to D1S206 $\left(\mathrm{Z}_{\max } 1.8, \theta=0\right)$. The loci $C O L 2 A 1, C O L 11 A 1$ and $C O L 11 A 2$ were excluded as the disease locus in family MS44. The COL5A2 locus could not be excluded and there was weak linkage to the D2S2261 marker $\left(\mathrm{Z}_{\max } 0.9, \theta=0\right)$. All four loci were excluded for families MS9 and MS32.

\section{Mutation Detection}

COL11A1 Amplification of COL11A1 cDNA was achieved using RNA from cultured dermal fibroblasts. Agarose gel electrophoresis of these products indicated

Table 1 Linkage analysis of families exhibiting type 2 vitreous phenotype with the four candidate genes

\begin{tabular}{|c|c|c|c|c|c|c|}
\hline $\begin{array}{l}\text { Family } \\
\text { number }\end{array}$ & $\begin{array}{l}\text { Total } \\
\text { individuals }\end{array}$ & $\begin{array}{l}\text { Total } \\
\text { affected }^{\mathrm{a}}\end{array}$ & COL $2 A 1$ & COL5A2 & COL11A1 & COL11A2 \\
\hline MS9 & $17 \quad(8)$ & $5(5)$ & $\mathrm{R}$ & $\mathrm{R}$ & $\mathrm{R}$ & $\mathrm{R}$ \\
\hline MS32 & $30(16)$ & $13(11)$ & $\mathrm{R}$ & $\mathrm{R}$ & $\mathrm{R}$ & $\mathrm{R}$ \\
\hline MS40 & $32(16)$ & $10(8)$ & $\mathrm{R}$ & $\mathrm{R}$ & $\mathrm{NR}\left[\mathrm{Z}_{\max }=3.3, \theta=0, \mathrm{D} 1 \mathrm{~S} 495\right]$ & $\mathrm{R}$ \\
\hline MS42 & $15(12)$ & $5(5)$ & $\mathrm{R}$ & $\mathrm{R}$ & $\mathrm{NR}\left[\mathrm{Z}_{\max }=1.8, \theta=0, \mathrm{D} 1 \mathrm{~S} 206\right]$ & $\mathrm{R}$ \\
\hline MS44 & $6(6)$ & 4 (4) & $\mathrm{R}$ & $\mathrm{NR}\left[\mathrm{Z}_{\max }=0.9, \theta=0, \mathrm{D} 2 \mathrm{~S} 2261\right]$ & $\mathrm{R}$ & $\mathrm{R}$ \\
\hline
\end{tabular}

${ }^{\mathrm{a}}$ Numbers in brackets indicate the subjects available to test. $\mathrm{NR}=$ non recombinant, $\mathrm{R}=$ recombinant, $\theta=$ recombination fraction Linkage analysis based on all of the markers detailed under Materials and Methods. Criteria for recombination are detailed in the text. The maximum lod score $\left(\mathrm{Z}_{\max }\right)$ obtained with the most informative marker at zero recombination. 
Table 2 Pedigree MS40: Type 2 vitreous phenotype

\begin{tabular}{|c|c|c|c|c|c|c|c|c|c|}
\hline \multirow[b]{2}{*}{$\begin{array}{l}\text { Pedigree } \\
\text { member }\end{array}$} & \multicolumn{2}{|c|}{ Ocular phenotype } & \multicolumn{2}{|c|}{ Articular phenotype } & \multicolumn{2}{|c|}{ Aural phenotype } & \multicolumn{3}{|c|}{ Oro-facial phenotype } \\
\hline & Myopia & $\begin{array}{l}\text { Retinal } \\
\text { detachment } \\
(+ \text { one eye }) \\
(++ \text { both eyes })\end{array}$ & $\begin{array}{l}\text { Joint } \\
\text { hypermobility } \\
\text { (abnormal } \\
\text { Beighton score) }\end{array}$ & $\begin{array}{l}\text { Radiological } \\
\text { joint } \\
\text { abnormality }\end{array}$ & $\begin{array}{l}\text { Conductive } \\
\text { loss }\end{array}$ & $\begin{array}{l}\text { Sensorineural } \\
\text { loss }\end{array}$ & $\begin{array}{l}\text { Midfacial } \\
\text { hypoplasia }\end{array}$ & $\begin{array}{l}\text { Abnormal } \\
\text { nasal } \\
\text { dev't }\end{array}$ & $\begin{array}{l}\text { Midline } \\
\text { cleft }\end{array}$ \\
\hline II-2 & +++ & + & ++ & + & 0 & ++ & + & + & 0 \\
\hline II-3 & ++ & 0 & 0 & + & 0 & ++ & 0 & 0 & 0 \\
\hline II-6 & + & ++ & 0 & + & 0 & ++ & 0 & + & 0 \\
\hline III-1 & + & 0 & $\mathrm{~N} / \mathrm{A}$ & 0 & 0 & + & + & + & $\mathrm{N} / \mathrm{A}$ \\
\hline III-4 & 0 & 0 & 0 & 0 & 0 & 0 & + & 0 & 0 \\
\hline III-5 & + & 0 & 0 & + & 0 & + & 0 & + & 0 \\
\hline III-7 & 0 & 0 & 0 & $+1-$ & 0 & + & + & 0 & 0 \\
\hline
\end{tabular}

0: absent; +: mild; ++: moderate; +++: severe; N/A: not available/applicable.

Note: Individual III-4, other than mild midfacial hypoplasia, abnormal vitreous phenotype was the only distinguishing feature from her unaffected non-identical twin. All affected patients have abnormal vitreous architecture of the type 2 phenotype.

Table 3 Pedigree MS42: Type 2 vitreous phenotype

\begin{tabular}{|c|c|c|c|c|c|c|c|c|c|}
\hline \multirow[b]{2}{*}{$\begin{array}{l}\text { Pedigree } \\
\text { member }\end{array}$} & \multicolumn{2}{|c|}{ Ocular phenotype } & \multicolumn{2}{|c|}{ Articular phenotype } & \multicolumn{2}{|c|}{ Aural phenotype } & \multicolumn{3}{|c|}{ Oro-facial phenotype } \\
\hline & Myopia & $\begin{array}{l}\text { Retinal } \\
\text { detachment } \\
(+ \text { one eye) } \\
(++ \text { both eyes })\end{array}$ & $\begin{array}{l}\text { Joint } \\
\text { hypermobility } \\
\text { (abnormal } \\
\text { Beighton score) }\end{array}$ & $\begin{array}{l}\text { Radiological } \\
\text { joint } \\
\text { abnormality }\end{array}$ & $\begin{array}{l}\text { Conductive } \\
\text { loss }\end{array}$ & $\begin{array}{l}\text { Sensorineural } \\
\text { loss }\end{array}$ & $\begin{array}{l}\text { Midfacial } \\
\text { hypoplasia }\end{array}$ & $\begin{array}{l}\text { Abnormal } \\
\text { nasal } \\
\text { dev't }\end{array}$ & $\begin{array}{l}\text { Midline } \\
\text { cleft }\end{array}$ \\
\hline $\mathrm{I}-2$ & + & + & 0 & + & 0 & + & + & 0 & 0 \\
\hline II-2 & + & $\begin{array}{l}\text { N/A } \\
\text { (laser } \\
\text { prophylaxis) }\end{array}$ & 0 & + & 0 & + & + & 0 & 0 \\
\hline II-3 & + & ++ & 0 & $\mathrm{~N} / \mathrm{A}$ & 0 & + & ++ & 0 & 0 \\
\hline III-2 & $+/-$ & 0 & 0 & 0 & 0 & 0 & 0 & + & 0 \\
\hline III-4 & ++ & 0 & 0 & $\mathrm{~N} / \mathrm{A}$ & 0 & + & + & + & 0 \\
\hline
\end{tabular}

0: absent; +: mild; ++: moderate; +++: severe; N/A: not available/applicable.

Note: All affected patients have abnormal vitreous architecture of the type 2 phenotype.

deletions from the coding sequences of both MS40 and MS42 (Figure 1). In the case of MS40 a smaller than expected band was seen in an amplification reaction encompassing bases 536-3551. Sequencing showed an in-frame deletion of $774 \mathrm{bp}$ removing 258 amino acids from the helical region of the molecule (Figure $2 \mathrm{a}$ ). Amplification of genomic DNA, using primers either side of the deleted region resulted in a $7.1 \mathrm{~kb}$ product for all of the affected members of the family, but no product from normal individuals (Figure 2b). It was therefore assumed that the $7.1 \mathrm{~kb}$ product presented the region of the mutant COL11A1 gene which contained a deletion. The genomic structure of COL11A1 is not yet known; however this deleted region of $C O L 11 A 1$ corresponds to exons 31-42 of $C O L 11 A 2$ which is $4 \mathrm{~kb}$ in length. Amplification of the same region of $C O L 11 A 1$ as a number of fragments showed that the exon/intron structure appeared to be the same as for COL11A2, but generally the introns were much larger (data not shown). This resulted in this region of COL11A1 being over $47 \mathrm{~kb}$ in length, meaning that around $40 \mathrm{~kb}$ was deleted in the mutant allele of MS40. The end points of the deletion were determined to be within two introns which were between bases 2663/2664 and bases $3437 / 3438$ of the cDNA sequence and were $3.8 \mathrm{~kb}$ and $6.2 \mathrm{~kb}$, respectively. Each of these introns contained a region of around $450 \mathrm{bp}$ sharing approximately 95\% identity. These sequences were homologous to a region in the L1 LINE family of repeats which are present throughout the human genome. ${ }^{32}$ Recombination between these two sequences appears to have been responsible for the mutation.

Analysis of cDNA between bases 930-1892 from MS42 detected a smaller deletion. Cloning and sequencing showed a loss of $54 \mathrm{bp}$ from the smaller RT-PCR product (data not shown). Amplification and sequencing of this region of the gene showed that the 54 bp corresponded to a complete exon (Gly16-Gln33), which was present in both alleles of an affected 


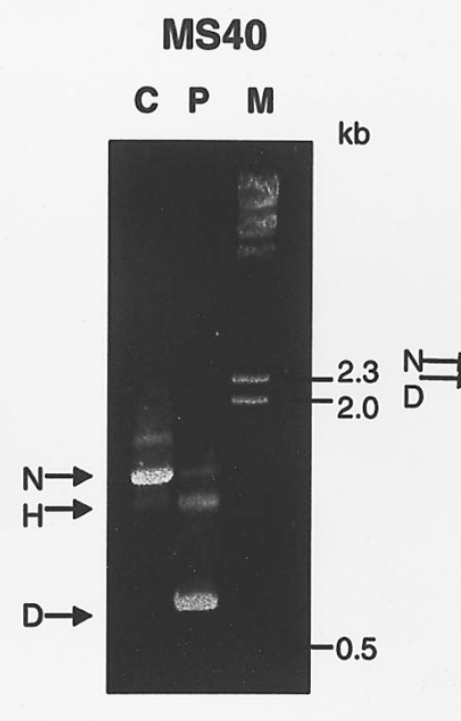

A

\section{MS42}

\section{P C M}

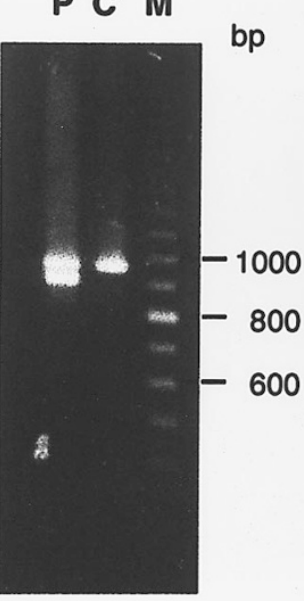

B
Figure 1 COL11A1 cDNA amplification. Using RNA from patient's $(P)$ cultured cells, regions 2196-3551 (A) and 930-1892 (B) of the COL11A1 cDNA sequence were amplified. Deletions $(D)$ were seen when compared to the normal $(N)$ sized product from control $(C) R N A$ and standard DNA markers $(M)$. Heteroduplexes $(H)$ were seen in the sample from MS40.

individual. The 5' donor splice sequence of the following intron was found to be normal in both alleles. However, one allele had a single base deletion which altered the $3^{\prime}$ acceptor splice site of the preceding intron, from the consensus ag to tg (Figure 3a). This lead to skipping of the $54 \mathrm{bp}$ exon from the mRNA, as seen in the RT-PCR product. The base pair deletion removed a $S f c I$ restriction site. Analysis of DNA from family members (Figure $3 \mathrm{~b}$ ) showed that whereas normal individuals were homozygous for the $S f_{c} I$ site, affected members were heterozygous and therefore all possessed the $1 \mathrm{bp}$ deletion.

COL5A2 Using cultured dermal fibroblast RNA from an individual of MS44, the cDNA for $\alpha 2(\mathrm{~V})$ collagen was amplified as $900 \mathrm{bp}$ and larger $(2-4 \mathrm{~kb})$ overlapping products. No abnormalities in size were observed. Direct sequencing of the complete open reading frame did not detect a change likely to be a causative mutation. Polymorphisms were seen, providing evidence that both alleles were expressed and amplified. These polymorphisms also confirmed the haplotype analysis obtained with flanking markers. a

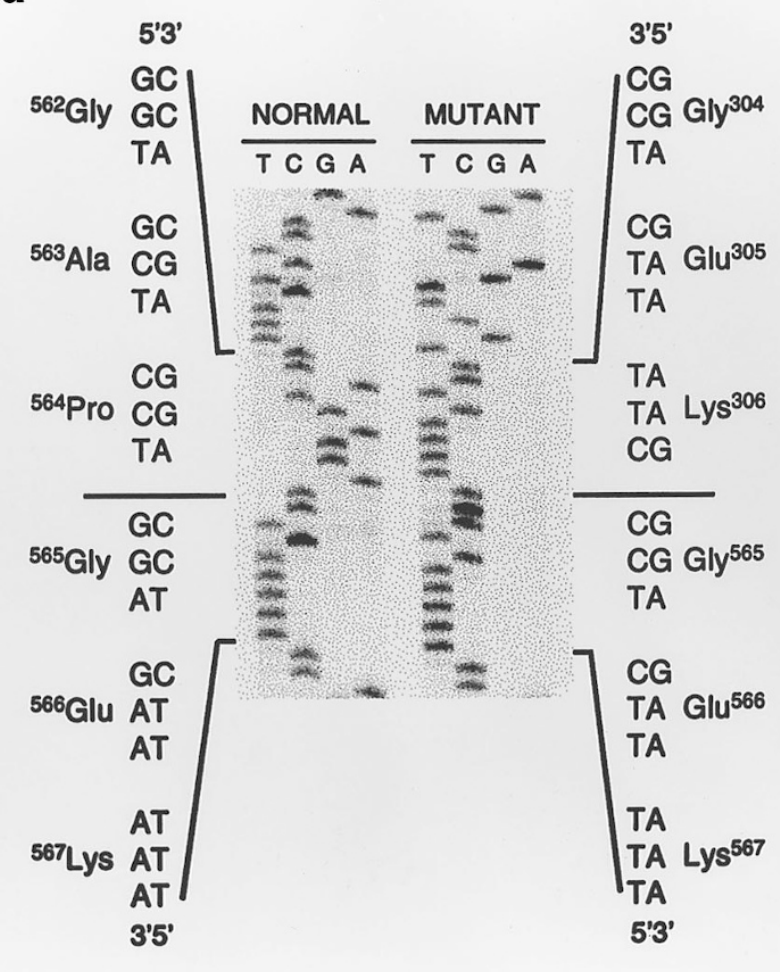

b

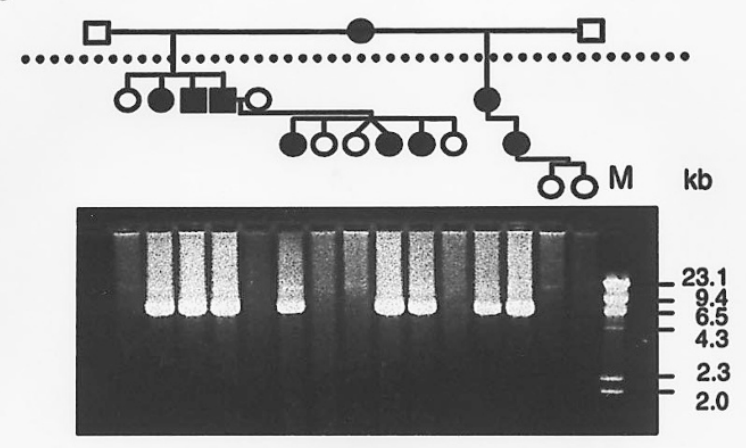

Figure 2 Analysis of MS40. Direct sequencing of the normal and deleted products seen in MS40 showed that 774 bp coding for amino acids 307-564 of the collagen helix were missing (2a). Amplification of this region of the gene resulted in a $7.1 \mathrm{~kb}$ product, from affected individuals $(\mathbf{2 b})$, only samples from patients below the dashed line appear on the gel.

\section{Discussion}

To date defects in two genes, COL2A1 and COL11A1 have been shown to cause the full Stickler syndrome phenotype, including ocular changes. ${ }^{8,9,16,33-36}$ In addition mutations in COL11A2 lead to a 'Stickler-like' phenotype, but without ocular abnormalities. ${ }^{19,20,22,37}$ In 
a

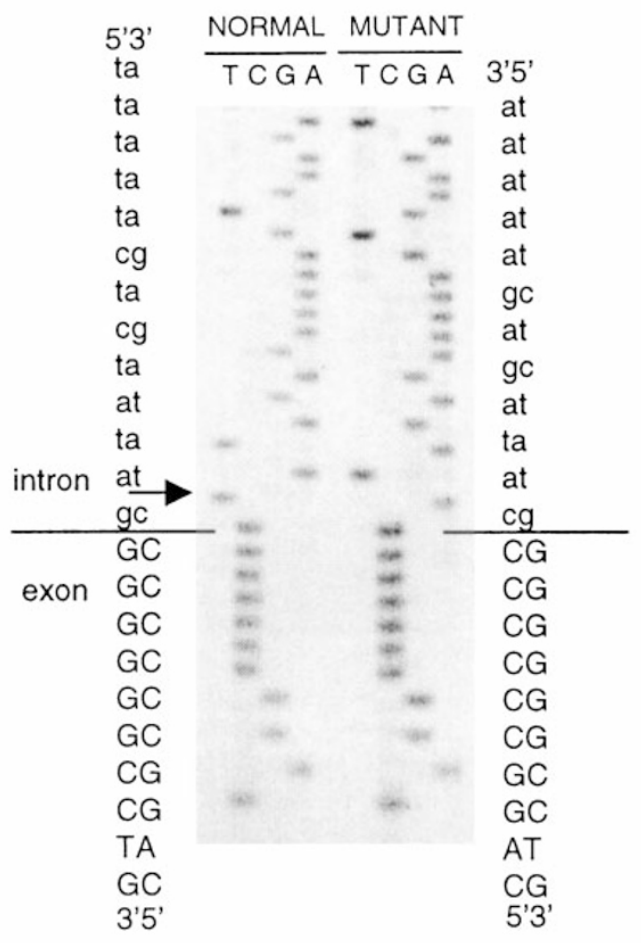

b

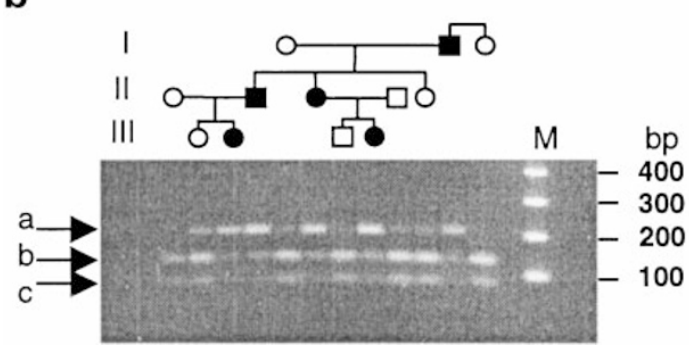

Figure 3 Analysis of MS42. Sequencing of genomic DNA (3a) found a $1 \mathrm{bp}$ deletion in one allele affecting the splice acceptor site and causing an 'in frame' exon skip. Analysis of the family showed that all of the affected individuals had this deletion which removed an Sfc I restriction site (3b) from an amplified DNA product (a) and resulted in lower amounts of the digested products ( $b$ and $c$ ).

bovine vitreous the product of COL11A2, $\alpha 2(\mathrm{XI})$ collagen, is replaced by $\alpha 2(\mathrm{~V})$ collagen, which co-assembles with the products of the COL2A1 and COL11A1 genes. ${ }^{23}$ Thus COL5A2 could also be considered as a candidate for Stickler syndrome. Relatively few COL2A1 Stickler mutations have been characterised $^{8,9,33-36}$ and only one COL11A1 mutation, ${ }^{16}$ In addition a COL11A1 exon skipping mutation has been described in the closely related Marshall syndrome. ${ }^{38}$

Heterogeneity within the Stickler syndromes therefore poses a diagnostic dilemma for molecular genetic analysis in sporadic cases, and any clinical differences which arise from defects in the alternative genes could provide a valuable indication of the gene involved. Although our proposed sub-classification may not be favoured by the non-ophthalmologist, it is potentially more useful in the clinical setting than a locus-based classification which requires a lengthy laboratory-based diagnosis. It also has the potential to optimise and reduce any subsequent laboratory confirmation by indicating the likely, and perhaps more importantly the unlikely, candidate genes for analysis. In our experience the vitreous phenotypes are characteristic and unlike the skeletal or auditory changes, the vitreous presents a unique opportunity for the direct biomicroscopic observation of the abnormalities of connective tissue architecture 'in vivo'.

Slit lamp examination can detect two different vitreous phenotypes in families with Stickler syndrome. Systemic manifestations are similar and do not reliably distinguish between these two sub-groups. ${ }^{14,15} \mathrm{We}$ have previously shown that one group of families with the type 1 'membranous' congenital vitreous anomaly were consistent with linkage to $\mathrm{COL} 2 \mathrm{Al} .^{12}$

We have confirmed our previous observation, that dominant negative mutations of COL11A1 cause Stickler syndrome with the type 2 vitreous phenotype. Here a further two families were found to be linked to that gene and the causative mutations characterised. Both lead to in-frame deletions from the triple helical region of the molecule, leaving an intact C-propeptide capable of heterotrimer formation with normal collagen $\alpha$-chains. One mutation causes exon skipping, the other is a multi-exon deletion from the central portion of the gene. All three pedigrees exhibit the type 2 or 'beaded' vitreous anomaly. The exon/intron structure of the COL11A1 gene has not yet been determined and so we are not able to assign exon numbers to these deleted regions. However the limited analysis we have performed here, and previously, ${ }^{16}$ suggests that at least for those regions coding for the collagen helix, the COL11A1 gene is identical in organisation to COL11A2. The exon skipping mutation would correspond to exon 15 in COL11A2 and the multi-exon deletion to exons 31-42. A major difference between COL11A1 and COL11A2 appears to be size. Most of the COL11A1 introns that we have amplified are larger than those of $C O L 11 A 2$. Indeed the deleted region in MS40 alone, at $40 \mathrm{~kb}$, is larger than the $28 \mathrm{~kb}$ COL11A2 gene. $^{31}$ Another $54 \mathrm{bp}$ exon-skipping mutation in COL11A1 caused Marshall syndrome ${ }^{38}$ and it was 
suggested that this was due to the more disruptive type of mutation compared with the previous glycine substitution seen in this molecule. ${ }^{16}$ The skipping mutation and the multi exon deletion described here should be just as disruptive as the mutant described as causing Marshall syndrome. Previously it had been thought that Marshall and Stickler syndromes may be one and the same and should not be segregated. ${ }^{39,40}$

Analysis of family MS44 with the type 2 vitreous abnormality, was consistent with COL5A2 as the disease locus. However, amplification of small and large cDNA products detected no deletions or insertions and sequencing of the complete open reading frame also revealed no significant changes. Polymorphisms were seen, indicating that both alleles were expressed, excluding a null allele. This in itself does not exclude COL5A2, but along with the observation that some patients with Ehlers-Danlos syndrome and COL5A2 mutations do not have vitreous changes, ${ }^{41}$ it suggests that COL5A2 is not the disease locus in this family. This hypothesis is substantiated by the data excluding the four loci tested for both families MS9 and MS32 indicating that further heterogeneity within Stickler syndrome remains to be resolved.

In summary, our genetic analysis of families with Stickler syndrome has provided evidence for another Stickler syndrome locus associated with the type 2 vitreous phenotype. Dominant negative mutations of COL11A1 are associated with the type 2 vitreous phenotype in Stickler syndrome and this substantiates the clinical subclassification proposed previously. ${ }^{12}$

\section{Acknowledgements}

The work presented here was partially funded by The Iris Fund for Prevention of Blindness.

\section{References}

1 Stickler GB, Belau PG, Farrell FJ et al: Hereditary progressive arthro-ophthalmopathy. Mayo Clinic Proc 1965; 40: 433-455.

2 Stickler GB, Pugh DG: Hereditary progressive arthroophthalmopathy II. Additional observations on vertebral abnormalities, a hearing defect, and a report of a similar case. Mayo Clinic Proc 1967; 42: 495-500.
3 Maumenee IH: Vitreo-retinal degeneration as a sign of generalised connective tissue diseases. Am J Ophthalmol 1979; 88: 432-449.

4 Francomano CA, Liberfarb RM, Hirose $\mathrm{T}$ et al: The Stickler syndrome: evidence for close linkage to the structural gene for type II collagen. Genomics 1987; 1: 293-296.

5 Knowlton RG, Weaver EJ, Struyk AF et al: Genetic linkage analysis of hereditary arthro-ophthalmopathy (Stickler syndrome) and the type II procollagen gene. Am J Hum Genet 1989; 45: 681-688.

6 Priestley L, Kumar D, Sykes B: Amplification of the COL2A1 3' variable region used for segregation analysis in a family with the Stickler syndrome. Hum Genet 1990; 85: $525-526$.

7 Bonaventure J, Philippe C, Plessis G et al: Linkage study in a large pedigree with Stickler syndrome - exclusion of COL2A1 as the mutant gene. Hum Genet 1992; 90: $164-168$.

8 Ahmad NN, Ala-Kokko L, Knowlton RG et al: Stop codon in the procollagen II gene (COL2A1) in a family with the Stickler syndrome (arthro-ophthalmopathy). Proc Natl Acad Sci USA 1991; 88: 6624-6627.

9 Brown DM, Nichols BE, Weingeist TA, Sheffield VC, Kimura AE, Stone EM: Procollagen II gene mutation in Stickler syndrome. Arch Ophthalmol 1992; 110: 1589-1593.

10 Williams CJ, Ganguly A, Considine E et al: $\mathrm{A}^{-2}>\mathrm{G}$ transition at the $3^{\prime}$ acceptor splice site of IVS17 characterizes the COL2A1 gene mutation in the original Stickler syndrome kindred. Am J Med Genet 1996; 63: 461-467.

11 Kuivaniemi H, Tromp G, Prockop DJ: Mutations in fibrillar collagens (type I, II, III and XI, fibril-associated collagen (type IX), and network-forming collagen (type X) cause a spectrum of diseases of bone, cartilage and blood vessels. Hum Mut 1997; 9: 300-315.

12 Snead MP, Payne SJ, Barton DE et al: Stickler syndrome: Correlation between vitreo-retinal phenotypes and linkage to COL 2A1. Eye 1994; 8: 609-614.

13 Snead MP, Yates JRW, Williams R, Payne SJ, Pope FM, Scott JD: Stickler syndrome Type 2 and linkage to the COL11A1 gene. Ann NY Acad Sci 1996; 785: 331-332.

14 Snead MP: Hereditary vitreopathy. Eye 1996; 10: 653-663.

15 Snead MP, Yates JRW: Clinical and molecular genetics of Stickler syndrome. J Med Genet 1999; 36: 353-359.

16 Richards AJ, Yates JRW, Williams R et al: A family with Stickler syndrome type 2 has a mutation in the COL11A1 gene resulting in the substitution of glycine 97 by valine in a1(XI) collagen. Hum Mol Genet 1996; 5: 1339-1343.

17 Li Y, Lacerada DA, Warman ML et al: A fibrillar collagen gene, COL11A1, is essential for skeletal morphogenesis. Cell 1995; 80: 423-430.

18 Marchant JK, Hahn RA, Linsenmayer TF, Birk DE: Reduction of type $\mathrm{V}$ collagen using a dominant-negative strategy alters the regulation of fibrillogenesis and results in the loss of corneal-specific fibril morphology. J Cell Biol 1996; 135: 1415-1426.

19 Sirko-Osadsa D, Murray MA, Scott JA, Lavery MA, Warman ML, Robin NH: Stickler syndrome without eye involvement is caused by mutations in COL11A2, the gene encoding the a2(XI) chain of type XI collagen. $J$ Pediatr 1998; 132: 368-371. 
20 Brunner HG, van Beersum SEC, Warman ML, Olsen BR, Ropers $\mathrm{H}-\mathrm{H}$, Mariman ECM: A Stickler syndrome gene is linked to chromosome 6 near the COL11A2 gene. Hum Mol Genet 1994; 3: 1561-1564.

21 van Steensel MAM, Buma P, de Waal Malefijt MC, van den Hoogen FHJ, Brunner HG: Otospondylomegaepiphyseal dysplasia (OSMED): Clinical description of three patients homozygous for a missense mutation in the COL11A2 gene. Am J Med Genet 1997; 70: 315-323.

22 Pihlajamaa T, Prockop DJ, Faber J et al: Heterozygous glycine substitution in the COL11A2 gene in the original patient with the Weissenbacher-Zweymüller syndrome demonstrates its identity with heterozygous OSMED (Nonocular Stickler syndrome). Am J Med Genet 1998; 80: 115-120.

23 Mayne R, Brewton RG, Mayne PM, Baker JR: Isolation and characterization of the chains of type V/type XI collagen present in bovine vitreous. J Biol Chem 1993; 268: 9381-9386.

24 Marshall D: Ectodermal dysplasia. Am J Ophthalmol 1958; 45: 143-156.

25 Shanske AL, Bogdanow A, Shpritnzen RJ, Marion RW: The Marshall syndrome: Report of a new family and review of the literature. Am J Med Genet 1997; 70: 52-57.

26 Dib C, Faure S, Fizames C et al: A comprehensive genetic map of the human genome based on 5,264 microsatellites. Nature 1996; 380: 152-154.

27 Deloukas P, Schuler GD, Gyapay G, Beasley EM, Soderlund C et al: A physical map of 30,000human genes. Science 1998; (www.ncbi.nlm.nih.gov/genemap).

28 Lee B, Vitale E, Superti-Furga A, Steinmann B, Ramirez F: $G$ to $T$ transversion at position +5 of a splice donor site causes skipping of the preceding exon in the type III procollagen transcripts of a patient with Ehlers-Danlos syndrome type IV. J Biol Chem 1991; 266: 5256-5259.

29 Cutting GR, McGinniss MJ, Kasch LM, Tsipouras P, Antonarakis SE: Physical mapping by PFGE localizes the COL3A1 and COL5A2 genes to a $35-\mathrm{kb}$ region on human chromosome 2. Genomics 1990; 8: 407-410.

30 Ott J: Estimation of the recombination fraction in human pedigrees: efficient computation of the likelihood for human linkage studies. Am J Hum Genet 1974; 26: 588-597.
31 Vuoristo MM, Pihlajamaa T, Vandenberg P, Prockop DJ, Ala-Kokko L: The human COL11A2 gene structure indicates that the gene has not evolved with the genes for the major fibrillar collagens. J Biol Chem 1995; 270: 22873-22881.

32 Smit AFA, Toth G, Riggs AD, Jurka J: Ancestral mammalian wide subfamilies of LINE-1 repetitive sequences. $J$ Mol Biol 1995; 246: 401-417.

33 Ahmad NN, McDonald-McGinn DM, Zackai EH et al: A second mutation in the type II procollagen gene (COL2A1) causing Stickler syndrome (arthro ophthalmopathy) is also a premature termination codon. $A m J$ Hum Genet 1993; 52: 39-45.

34 Brown DM, Vandenburgh K, Kimura AE, Weingeist TA, Sheffield VC, Stone EM: Novel frameshift mutations in the procollagen 2 gene $(C O L 2 A 1)$ associated with Stickler syndrome (hereditary arthro-ophthalmopathy). Hum Mol Genet 1995; 4: 141-142.

35 Williams CJ, Ganguly A, Considine E et al: $\mathrm{A}^{-2}>\mathrm{G}$ transition at the $3^{\prime}$ acceptor splice site of IVS17 characterizes the COL2A1 gene mutation in the original Stickler syndrome kindred. Am J Med Genet 1996; 63: 461-467.

36 Ritvaniemi P, Hyland J, Ignatius J, Kivirikko KI, Prockop DJ, Ala-Kokko L: A fourth example suggests that premature termination codons in the COL2A1 gene are a common cause of the Stickler syndrome. Analysis of the COL2A1 gene by denaturing gradient gel electrophoresis. Genomics 1993; 17: 218-221.

37 Vikkula M, Mariman ECM, Lui VCH et al: Autosomal dominant and recessive osteochondrodysplasias associated with the COL11A2 locus. Cell 1995; 80: 431-437.

38 Griffith AJ, Sprunger LK, Sirko-Osadsa DA, Tiller GE, Meisler MH, Warman ML: Marshall syndrome associated with a splicing defect at the COL11A1 locus. Am J Hum Genet 1998; 62: 816-823.

39 Baraitser M: Marshall/Stickler syndrome. J Med Genet 1982; 19: 139-140.

40 Winter RM, Baraitser M, Laurence KM, Donnai D, Hall CM: The Weissenbacher-Zweymuller, Stickler, and Marshall syndromes: Further evidence for their identity. Am J Med Genet 1983; 16: 189-199.

41 Richards AJ, Martin S, Nicholls AC, Harrison JB, Pope FM, Burrows NP: A single base mutation in COL5A2 causes Ehlers-Danlos syndrome. J Med Genet 1998; 35: 846-848. 